DOI: 10.12731/wsd-2017-3-62-75

UDC 619:616.995.42:615

\title{
MULTIPLE-FUNCTION ACTIVITY OF THE PREPARATION ARTAFIDIN ${ }^{1}$
}

\section{Shamanskaya L.D., Butakov E.I.}

The article presents testresults of the preparation Artafidinthat fightsparasitic fauna of plants, animals and birds. Artafidin effectiveness against various kinds of aphids has been estimated 96.5-100\%on horticultural crops, 97.4-98\%on melons and $100 \%$ on vegetable crops. The preparation has proved to be highly selective towards the beneficial fauna. No resistance to Artafidin against Aphis pomiDeg.was foundat its check studiesat a long-term apple station.

Artafidin has shown 100\% effectiveness against the ixodicticks Dermacentor marginatus Sulzerat a concentration of $4 \%$ while performing treatment with spray material and at a concentration of $3 \%$ while using foam. High sensitivity to Artafidin in the menoponidae Menacanthus stramineus (Nitzsch, 1818), being parasites on chickens, has been found. Ovicide effect of the preparation against the parasite ensures a prolonged protective effect.

The use of Artafidin against various kinds of parasitic fauna removes a number of restrictions on the use of protection products, contributes to ecologically friendly agricultural production and cattle breeding as well as provides ecological security.

Keywords: exophytes; plants; animals; chitosan preparation; effectiveness; aftereffect.

\section{ПОЛИФУНКЦИОНАЛЬНАЯ АКТИВНОСТЬ ХИТОЗАНОВОГО ПРЕПАРАТА АРТАФИДИН}

\section{Шаманская Л.Д., Бутаков Е.И.}

В статье приводятся результаты испытаний хитозанового препарата Артафидин против паразитарной фауны растений, животных и

${ }^{1}$ Шаманская Л.Д., Бутаков Е.И. Полифункциональная активность хитозанового препарата Артафидин // В мире научных открытий, 2016. № 10(82). С. 93109. doi:10.12731/wsd-2016-10-93-109. 
птиц.. Эффективность Артафидина против различных видов тлей на садовых культурах составила 96,5-100, на бахчевых 97,4-98,0, на овошных - 100\%. Препарат показал высокую избирательную активность в отношении полезной фауны. Не отмечено появление устойчивости к препарату Артафидин при его испьттании в многолетнем стационаре яблони против AphispomiDeg.

Артафидин показал 100\%-ю эффективность против иксодового клещуа Dermacentor marginatus Sulzer в концентрации 4\% при обработке рабочим раствором и 3\% при обработке пеной.

Выявлена высокая чувствительность к Артафидину у пухопероеда Меnacanthus stramineus Nitzsch, 1818 паразитирующего на курах. Овицидное действие препарата в отночении этого паразита обеспечивает длительный зашитный эффект.

Использование Артафидина против различных представителей паразитарной фауны снимает цельлй ряд ограничений по применению средств защуиты, способствует получению экологически чистой продукции растениеводства и животноводства и обеспечивает безопасность окружающеей среды.

Ключевые слова: экзопаразиты; растения; животные;хитозановый препарат; эффективность; последействие.

\section{Introduction}

Among numerous negative aftereffects of the use of chemical plant protection products, the following are considered the most significant: environmental and crops pollution with toxic residues, beneficial fauna extermination as well as pestsresistance development. In this regard, organic farming is getting more widespread on a global scale, which has heightened the interest in learning and putting into practice methods of crops cultivation that reduceand exclude pollution of both the produce and environment with harmful substances, especially pesticides and agrochemicals [1]. Non-chemical protection techniques are being the choice as they neither pollute the environment nor produce any toxic residues; they also contribute to the beneficial fauna preservation.

For a long time, the chemical pesticides used in crop production were widely used in cattle breeding as well. It was for animals and birdsprotection against exophytesthat Malathion, Sevin, DDT and other types of pesticideswere applied. These chemical preparations are characterized by their hypertoxicity and cumulative properties. Their use in cattle breeding is severely restricted. 
Thus, it is of great importance to come up with new preparations that have the same broad spectrum as chemical pesticides, but, unlike them, are safe for humans and the environment [2].

One promising area of research is to develop preparations based on natural biologically active substances [3]. Of theseones, the most widely used are now certain preparations based on chitosan, such as Fitohit, Zolushka, Agro-Hit, Mikosan, Narciss and Ecogel. Several of these preparations were developed in Russia. Of these, Narcissus and Ecogel are the ones being most widely used in crop farming.

Chitosan and preparations based on chitosan are neither toxic to humans and the environment nor cause resistance in pathogenic microorganisms. Chitosan has fungicide [4], antibacterial [5] and anti-viral [6] effects as well as is capable of inducing a nonspecific wide spectrum disease resistance in plants and can be used to protect plants from diseases of different etiology.

One of the unique biological activities of chitosan is considered to be its ability to induce resistance to plant viral diseases, as well as inhibit viral infection in animals [7].

Chitosan contributes to reducing nematode population density $[8,9]$. Concerning other types of pests, chitosan effectiveness has been insufficiently studied so far.

The purpose of the study is to examine the biological activity of the chitosan preparation Artafidin against parasitic fauna of plants, animals and birds.

\section{Materials and methods of research}

Main research activitieswere carried out atthe Siberian Horticultural Research Institute named after M.A. Lisavenko.

Artafidin testing against aphids, being horticultural crops pests, was performed in apple, black currant, sweet viburnum and raspberry industrial plantations of the Horticultural Research Institute experimental field, against aphids, being vegetables and melonspests, at garden plots, against scales - on houseplants. Experiments on the spraying of these crops were carried out in four repetition stages using a Kwazar backpack sprayer. Liquid insecticidal soap was tested as the experimental reference standard. The control plants were not treated.

Dead pests count was performed 1 day after treatment using an MBS-9 microscope to scan ten damaged leaves in each replicate while calculating the number of live and dead individuals according to the technique by K. Gar [1963] [10]. The population density of the colonies was taken into account. 
The colonies numbering up to 30 individuals were referred to as lowly-populated, whereas those numbering up to over 250 as highly-populated ones.

The three-factor experiment to test Artafidin on horticultural crops includedFactor A factor as the preparation, Factor B - aphid species, Factor C population density of the colonies.

The way Artafidin treatment affects protected plants was tested at a longterm apple station on the Zhar-Ptitsa apple variety. The way plants develop under different treatment conditions was analyzed by measuring growth of all plants at the end of the vegetation season; crop yield was measured on two plants in each replicate. The fruit biochemical analysis was carried out at the biochemistry laboratory of the Horticultural Research Institute using the conventional techniques.

The statistical data processing was done by the analysis-of-variance method [11].

The testing of Artafidina caricide activity against ixodicticks Dermacentor marginatus (Sulzer, 1776) was conducted in the Altai Research and Development Institute of Cattle Breeding Technology using the standard technique [12], against menoponidae Menacanthus stramineus (Nitzsch, 1818) it was the technique by D.I. Blagoveshchensky that was used [1972] [13].

\section{Results and discussion}

The chitosan preparation Artafidin was developed atthe Siberian Horticultural Research Institute named after M.A. Lisavenko. Liquid insecticidal soap and organic-mineral fertilizer Artemia obtained from cysts of Artemia sp., found in salt lakes of the AltaiTerritory, were used as raw materials. The structure of the Artemia sp. hydrolysatecontains 35\% solid matter (proteins and amino acids, fats and fatty acids, chitin and chitosan), $0.5 \%$ total nitrogen, $12 \%$ total phosphorus and traces of $\mathrm{Cu}, \mathrm{Zn}, \mathrm{Co}, \mathrm{Mn}$ [14]. The Artemia sp.hydrolysate also contains 35 fatty acids, including arachidonic acid [15], which is characterized as having a growth stimulating effect.

Artafidinwas tested against the most common group of sap-sucking pests of horticultural crops, i.e., the following species of aphids: green apple (Aphis pomi Deg, 1773), gooseberry (Aphis grossulariae Kalt, 1843), black sweet viburnum (Aphis viburni Giovanni Antonio Scopoli, 1763) and raspberry (Aphis idaiei Goot., 1912).

Numerous colonies of these species of aphids live in the tops of the growing shoots, slowing their growth and development, reducing winter hardiness of the plants. The harmfulness of aphids is exacerbated by the fact that they can be carriers of dangerous viral diseases. 
The preliminary tests of the Artemia sphydrolysate in pure form as well as at a concentration of $0.3-1 \%$ showed its weak insecticidal activity against aphids of various species due to poor wettability of the latter. Insecticidal soap, tested as the experimental reference standard, causes death of the pests in lowly-populated colonies at $95.4-100 \%$ due to its plasmatic andskin dehydrating effect. In highly-populated colonies the insecticidal soap treatment effectiveness against A.grossulariae decreased to $29.3 \%$, while against A.idaiei it decreased to $5.7 \%$.

It is the content of the Artemia sp. hydrolysate in Artafidin that enhances theinsecticidal soap toxic effect, probably as it contains arachidonic acid, the one that has insecticidal properties [16]. In case $0.5 \%$ Artafidin was applied, the aphids exterminationrate failed to exceed $90 \%$ (Table 1).

Table 1.

The preparations effectiveness against various species of aphids onhorticultural crops

\begin{tabular}{|c|c|c|c|c|c|c|}
\hline \multirow[b]{2}{*}{ Preparation } & \multirow{2}{*}{$\begin{array}{l}\text { Concentra- } \\
\text { tion, } \%\end{array}$} & \multirow{2}{*}{$\begin{array}{l}\text { Population } \\
\text { density of } \\
\text { the colonies }\end{array}$} & \multicolumn{4}{|c|}{ Aphids extermination rate, $\%$} \\
\hline & & & A. pomi & $\begin{array}{l}\text { A. grossu- } \\
\text { lariae }\end{array}$ & A. viburni & A. idaiei \\
\hline \multirow{2}{*}{$\begin{array}{l}\text { No treat- } \\
\text { ment - con- } \\
\text { trol }\end{array}$} & \multirow{2}{*}{-} & low & 0.10 & 0.20 & 0.15 & 0.20 \\
\hline & & high & 0.30 & 6.90 & 2.50 & 3.50 \\
\hline \multirow{2}{*}{$\begin{array}{l}\begin{array}{l}\text { Liquid soap } \\
\text { (reference } \\
\text { standard) }\end{array} \\
\end{array}$} & \multirow[b]{2}{*}{1} & low & 100 & 95.4 & 100 & 97.0 \\
\hline & & high & 90.8 & 29.3 & 97.3 & 5.7 \\
\hline \multirow{8}{*}{ Artafidin } & \multirow{2}{*}{0.5} & low & 87.4 & 85.6 & 90.0 & 63.2 \\
\hline & & high & 85.4 & 74.5 & 88.9 & 41.8 \\
\hline & \multirow{2}{*}{1} & low & 100 & 100 & 100 & 100 \\
\hline & & high & 99.7 & 97.7 & 96.9 & 96.5 \\
\hline & \multirow{2}{*}{1.5} & low & 100 & 100 & 100 & 100 \\
\hline & & high & 99.3 & 98.4 & 97.3 & 98.6 \\
\hline & \multirow{2}{*}{2} & low & 100 & 100 & 100 & 100 \\
\hline & & high & 99.2 & 99.3 & 97.8 & 99.1 \\
\hline $\begin{array}{l}\mathrm{HCP}_{05} \text { for } \\
\text { thefactors }\end{array}$ & - & - & \multicolumn{4}{|c|}{$\begin{array}{c}\mathrm{A}-0.13 ; \mathrm{B}-0.1 ; \mathrm{C}-0.07 ; \mathrm{AB}-0.15 \\
\mathrm{AC}-0.18 ; \mathrm{BC}-0.25 ; \mathrm{ABC}-0.36\end{array}$} \\
\hline
\end{tabular}

As the concentration of the spray material was increased to $1 \%$, it enhanced the treatment effectiveness up to $100 \%$ in lowly-populated colonies and to 96.5-99.7\% in highly-populated ones. Further increase in the concentration of 
Artafidinseems to be impractical as it fails to significantly affect the treatment effectiveness.

According to the results of the statistical data processing the maximum share of Factor A was $82.8 \%$, Factors AB - 5.2\%, Factors AC- $4.1 \%$, Factors $\mathrm{ABC}-3.5 \%$, other Factors $-0.07-2.1 \%$.

Further Artafidin effectiveness testing was performed at a long-term apple station, the plant shoots being densely populated by the green apple aphid.

The insecticidal soap entry-level effectiveness was 93.1\%, the one of Artafidin being $95.8 \%$. In the latter case, individuals, that stayed alive, failed to feed, and were not observed on the plants within 16 days after the treatment was performed. Re-colonization of the plants was observed 21 days after the spraying, the pest population being relatively small (6 individuals per leaf), while the population density on the leavesthat had been treated with insecticidal soap over this period of time increased to 45 individuals per leaf, further population density rate decreasing significantly due to predatory insects' vigorous activity. The long-term protective effect of Artafidin can reliably protect apple trees against the green apple aphid after a single spraying.

The apple trees treatment with Artafidin contributed to the shoots quick growth. By the end of the vegetation season, the growth increase was estimated 2.8 times as highcompared with the control sample and 1.5 times higher compared with the shoots that had been treated with insecticidal soap. The analysis of variance results showed that this difference is statistically valid. We believe that the stimulatory effect of Artafidinis related to the fact that the Artemia sp. hydrolysatecontains elements of plant nutrition and growth promoters, i.e. chitin, succinic acid and arachidonic acid.

Upon treating the plants with Artafidin the fruit quality improvement was observed (as compared with the control sample) that include increase in the sugar content, content of vitamin $\mathrm{C}$ and pectin.

The sugar-acid ratio, which characterizes fruit palatability traits, was estimated as 23.8 in the first case and 14.1 in the second one. The lowest sugar-acid ratio of 10.0 was observed upon treating the apple trres with insecticidal soap.

The use of Artafidinto protect apple trees from $A$. pomi allows growing ecologically friendly produce, which is considered an advantage in comparison with the chemical protection products.

The test results of the chitosan preparation effectiveness against various species of aphids on vegetable and melon crops have shown that when $1 \%$ Artafidin was applied, the extermination rate of the Brevicoryne brassicae L., 1758 increased from 82.4 to $100 \%$ in comparison with the experimental refer- 
ence standard. Liquid insecticidal soap ensured $100 \%$ extermination rate of the pests provided the spray material concentration was increased to $2 \%$.

The effectiveness of liquid insecticidal soap at a concentration of $1 \%$ against Aphis gossypii Glov., 1877 being sprayed over cucumbers and watermelons amounted to $70.4-74.2 \%$. It reached $92.4-94.6 \%$ only once the spray material concentration had been doubled. Artafidin provided high treatment effectiveness (97.4-98.0\%) against these kinds of aphids when the 1\% spray material was applied.

The effectiveness testing of the chitosan preparation Artafidin (1\%) showed its ability to be used not only against various kinds of aphids, but also against scales on the house plants with $99 \%$ effectiveness. Insecticidal soap (2\%) provided $73.3 \%$ extermination rate of this kind pests. The tests have shown that Artafidin can be used for protection against scales on virtually all house plantsdue to its high wetting activity.

High sensitivity to Artafidinhas been found in black-veined white caterpillars (Aporiacrataegi L., 1758) of the $1^{\text {st }}$ age. Their extermination rate, once $1 \%$ and $2 \%$ spray material had been applied, was $98.2 \%$ and $100 \%$, respectively. Artafidin effectiveness decreased to $70.3-82.4 \%$ when the caterpillars had come of the $2^{\text {nd }}$ age during the stage of winter nests formation.

According to the test results, Artafidin has proved to be highly selective towards the beneficial entomofauna and acarofauna. Thus, predatory ticks on apple trees as well as larvae of various species of predatory gall midges on fruit, berry, vegetable and melon crops fully retain their viability as the Artafidin recommended concentration of $1 \%$ is applied, while the use of insecticidal soap at an effective concentration of $2 \%$ caused death of $35.8 \%$ of predatory gall midge larvae.

The tests, carried out at the long-term experimental field, failed to reveal any resistance to Artafidinin A. pomi.

Further studies included the chitosan preparation Artafidin testing against ixodic (pasture) ticks, being temporary external parasites of the vertebrates. Ixodic ticks are the only carriers of pathogens that cause piroplasmosis, theileriosis, babesiosis, nuttaliosis, tick paralysis, tick bite fever, leptospirosis, spring-summer encephalitis in humans [17, 18, 19, 20]. In Russia, this type of ticks is involved in the spread of 20 animal diseases that result in significantly reduced milk productivity of livestock, whereas the mortality rate can reach up to $60-90 \%$.

Dermacentormarginatus (Sulzer, 1776) was used as an experimental object. The tests were carried out in a laboratory environment. 
Absolute (100\%) effectiveness of Artafidin against this species was obtained by treatmentwith the $4 \%$ spray material (Table 2 ).

Table 2 .

Artafidin effectiveness against $D$. marginatus

\begin{tabular}{|l|c|c|c|c|}
\hline \multirow{2}{*}{ Variant } & \multicolumn{4}{|c|}{ Ticks extermination rate, \% } \\
\cline { 2 - 5 } & \multicolumn{2}{|c|}{ spray material treatment } & \multicolumn{2}{c|}{ foam treatment } \\
\cline { 2 - 5 } & in $24 \mathrm{hrs}$ & in $48 \mathrm{hrs}$ & in $24 \mathrm{hrs}$ & in $48 \mathrm{hrs}$ \\
\hline No treatment - control & 0.1 & 0.2 & 0.2 & 0.1 \\
\hline Artafidin-1\% & 20.6 & 75.8 & 53.3 & 86.6 \\
\hline Artafidin-2\% & 15.0 & 82.5 & 26.0 & 82.6 \\
\hline Artafidin-3\% & 36.5 & 93.5 & 77.5 & 100 \\
\hline Artafidin-4\% & 72.0 & 100 & 90.0 & 100 \\
\hline $\mathrm{HCP}_{05}$ & 0.53 & 0.55 & 0.61 & 0.36 \\
\hline
\end{tabular}

While the ticks were treated with foam, the $100 \%$ extermination rate was obtained at a lower concentration of Artafidin (3\%).

At further stages of Artafidin effectiveness testing, along with other products based on natural biologically active substances, it was tested against menoponidae M. stramineus (Nitzsch, 1818), being parasites on chickens. The presence of this ectoparasite on birdscauses mallophagosis that results in a significant economic damage to the poultry industry in many countries [21]. Currently, in Russia various sorts of powders, solutions or shampoos containing synthetic pyrethroids and carbamate insecticides are used to protect the poultry from menoponidae. They fail to exhibit ovicidal action, as well as repeated treatments are required. After the treatment is performed, the eggs and poultry meat should be excluded from consumption for 1 month.

Artafidin effectiveness testing against $M$. stramineus in a laboratory environment has shown high sensitivity of this type of pests to Artafidin and other preparations based on natural biologically active substances. At both high $(1-4 \%)$ andextremely low concentrations $(0.001-0.0005 \%)$ the treatment effectiveness was $100 \%$ (Table 3 ).

M. stramineus high sensitivity to the treatment is due to the fact that once their ritating agents get inside the respiratory chambers, they affect the peripheral nervous system and damage the respiratory muscles, which leads to the death of the parasite. The chemical preparation Neostomasan, tested at a concentration of $0.001 \%$, has also provided $100 \%$ mortality of the pest.

Artafidin effectiveness in stationary conditions was tested at the Blagoveshchenskaya poultry farm of the Altai Territory. Prior to the treatment the 
massive clusters of adult parasites around the chickens' abdomen areahad been found. The chickens were treated by immersing the whole body (head up), followed by a vigorous manual handling of the head and other body parts. The treatment of the birds neither had negative effect on their condition nor affected the egg-laying intensity or the main parameters of the blood composition.

Table 3.

\section{Effectiveness of preparations based on natural biologically active substances against $M$. stramineus}

\begin{tabular}{|c|c|c|c|c|c|c|c|c|c|}
\hline \multirow{3}{*}{ Preparation } & \multicolumn{8}{|c|}{ M. stramineus extermination rate, \% } \\
\cline { 2 - 12 } & \multicolumn{10}{|c|}{ at a preparation concentration, \% } \\
\cline { 2 - 11 } & $4-1$ & 0.5 & 0.25 & 0.1 & 0.05 & 0.025 & 0.01 & 0.001 & 0.0005 \\
\hline Afidin & 100 & 100 & 100 & 100 & 100 & 100 & 100 & 100 & 100 \\
\hline Artafidin & 100 & 100 & 100 & 100 & 100 & 100 & 100 & 100 & 100 \\
\hline Vita-Start & 100 & 100 & 100 & 100 & 100 & 100 & 100 & 100 & 100 \\
\hline Fos & 100 & 100 & 100 & 100 & 100 & 100 & 100 & 100 & 100 \\
\hline Neo & 100 & 100 & 100 & 100 & 100 & 100 & 100 & 100 & - \\
\hline Formicide & 100 & 100 & 100 & 100 & 100 & 100 & 100 & 100 & 100 \\
\hline $\begin{array}{c}\text { Neostomasan (reference } \\
\text { standard) }\end{array}$ & - & - & - & - & - & - & - & 100 & - \\
\hline No treatment - control & \multicolumn{10}{|c|}{$0.09-0.4$} \\
\hline
\end{tabular}

The birds were then periodically inspected for the presence of live parasites and their larvae during the post-treatment period. Ovicidal action of the preparations was not specifically taken into account, but all the pests' eggs seem to have died after the treatment had been effected, since the protective effect period of the preparation was 1.5 months long and neither larvae nor adult insects were found on the treated poultry. We assume that death of the eggs is related to the waxy coatingdestruction, the one being required for the egg to be able to attach itself to the feather.

The preparation Artafidin, that has proved to be effective against $M$. stramineus, contains notoxic ingredients, which seems to be an advantage compared withthe chemical preparation Neostomasan. Ovicidal action of Artafidin provides long-term protection. Its use allows to lift restrictions on the eggs and poultry meat consumption after treatment.

\section{Conclusion}

The chitosan preparation Artafidin, developed on the basis of liquid insecticidal soaps and organic-mineral fertilizer Artemia, is characterized by 
a multiple-function activity against various representatives of the parasitic fauna.

$1 \%$ Artafidin is $96.5-100 \%$ effective against aphids, being a common group of sap-sucking pests on horticultural crops, it is $97.4-98.0 \%$ effective against a phids on melons, is $100 \%$ effective against $B$. brassicae, and is $82.4-100 \%$ effective against $A$. crataegi caterpillars at early ages. In addition, this preparation has proved to be highly selective towards the beneficial fauna.

The long-term protective effect of Artafidin contributes to a good phytosanitary condition of the plants after a single spraying against $A$. pomi.

No formation of $A$. pomi stable populations at the long-term apple station was observed after Artafidin had been applied.

Treating apple trees with Artafidinpromotes active plant growth and improves the produce quality.

Artafidin provesto be $100 \%$ effective against D. marginatus once either $4 \%$ spray material or $3 \%$ foam is used.

High sensitivity to Artafidin in M. stramineus and its ovicidal activity providesa long-term protective effect. Its use allows to lift restrictions on the eggs and poultry meat consumption after treatment.

Artafidin fights against the parasitic fauna of plants and animals as well as helps to ensure ecologically friendly crops and livestock production, providing a safe environment.

\section{References}

1. Zakharenko V.A. Zashchita i karantin rasteniy. 2015. № 11, pp. 3-6.

2. International Code of Conduct of the Distribution and Use of Pesticides (Amended version). FAO - Food and agriculture organization of the United Nations, Rome, 1990. 20 p.

3. Shamanskaya L.D. Sibirskiy vestnik sel'skokhozyaystvennoy nauki. 2012. № 1, pp. 53-60.

4. Park K. et al. Variation of antifungal activities of chitosans on plant pathogens. Journal of Microbiology and Biotechnology. 2002. № 12, pp. 84-88.

5. Raafat D., Bargen K., Haas A., Sahl H.G. Insights into the mode of action of chitosan as an antibacterial compound. Applied and Environmental Microbiology. 2008. Jun. № 74 (12), pp. 3764-3773.

6. Pestov A.V., Bondar' Yu.A., Mirsaev T.D., Skorik Yu.A., Yatluk Yu.G. Sovremennye perspektivy $v$ issledovanii khitina i khitozana: materialy Vos'moy Mezhdunarodnoy konferentsii. Kazan', 13-17 iyunya 2006 [Current perspectives 
in the study of Chitin and Chitosan: ma-rials Eighth International Conference. Kazan, on June 13-17, 2006]. Moscow, 2006, pp. 233-235.

7. Chirkov S.N. Novye dostizheniya $v$ issledovanii khitina $i$ khitozana: materialy Shestoy Mezhdunarodnoy konferentsii [New achievements in the study of Chitin and Chitosan: Proceedings of the Sixth International conference]. M.: VNIRO, 2001, pp. 120-123.

8. Kozhushko I.B. Zashchita i karantin rasteniy. 2003. № 8. P. 29.

9. Penf M.A. Biological pesticidae based on chitosan and entomopathogenic nematodes / Patent EP 1332676 (Bl). FR. Publication date 21.07.2004.

10. Gar K.A. Metody ispytaniya toksichnosti i effektivnosti pestitsidov [Methods for testing the toxicity and efficacy of pesticides]. M., 1963. $286 \mathrm{p}$.

11. Dospekhov B.A. Metodika polevogo opyta [Methods of field experience]. M.: Kolos, 1986. 502 p.

12. Dezinsektsiya. Metody opredeleniya effektivnosti insektitsidov, akari-tsidov, regulyatorov razvitiya irepellentov, ispol'zuemykh $v$ meditsinskoy dezinsektsii. NMU 3.5.2. 1759-03. P. 4.18. Metody otsenkieffektivnosti sredstv (skabitsidov) dlya unichtozheniya chesotochnykh kleshchey. 28 sentyabrya $2003 \mathrm{~g}$ [Pest. Methods for determining the effectiveness of insecticides, Akari-cides, the development of regulators and repellents used in medical disinfestation. NMU 3.5.2. 1759-03. P. 4.18. Methods of assessment of the effectiveness of (skabitsidov) to kill scabies mites. September 28, 2003]. $87 \mathrm{p}$.

13. Blagoveshchenskiy D.I. Metody issledovaniy vshey (Siphunculata) [Research Methods lice (Siphunculata)]. Leningrad: Nauka. 1972. 87 p.

14. Vereshchagin A.L., Prishchenko Yu.E., Bryukhanov V.A., Kuz'menko I.A., Antonova O.I. Proizvodnye khitozana i stimulyatory rosta v sel'skom khozyaystve: Materialy 3-ey mezhregional'noy nauchno-prakticheskoy konferentsii [Derivatives of chitosan and growth promoters in agriculture: Proceedings of the 3rd inter-regional scientific-practical conference]. Biysk: Izd. Alt. gos. tekh. un-ta, 2005, pp. 5-8.

15. Batashov E.S. Proizvodnye khitozana v stimulyatory rosta v sel'skom khozyaystve: Materialy 5-y Mezhregional'noy nauch.-prakt. konferentsii 25 marta 2008 goda [Derivatives of chitosan in the sti-pack for growth in agriculture. Proceedings of the 5th Inter-regional scientific-practical. Conference March 25, 2008]. Biysk. 2008, pp. 10-13.

16. Il'inskaya L.I., Ozertsovskaya O.L. Prikladnaya biokhimiya i mikrobiologiya. 1998. V. 34, № 5, pp. 467-479.

17. Hartung, Thomas, Rauter, Carolin. Prevalence of Borrelia burgdorferi sensu lato genospecies in Ixodesricinus ticks in Europe. A metaanalysis American 
Society for Microbiology. Applied and Environmental Microbiology. Biological sciences. Vol. 71. No. 11 (November 2005), pp. 7203-7216.

18. Grey J.S., Kahl O.In. Ticks as vectors of zoonotic pathogens in Europe. Halliday R.B., Walter D.E., Proctor H.C., Norton R.A., Colloff M.J., editors. Acarology: Proceedings of the 10th International Congress. Melbourne: CSIRO Publishing; 2001, pp. 547-51.

19. Ruiz-Fons F., Fernández-de-Mera I.G., Acevedo P. et al. Ixodid ticks parasitizing Iberian red deer (Cervus elaphus hispanicus) and European wild boar (Susscrofa) from Spain: geographical and temporal distribution. Journal Article, Re-search Support, Non-U.S. Gov't Vet. Parasitol. Aug 31. 2006. 140 (1-2):133-42.

20. Yano Y., Saito-Ito A., Anchalee D., Takada N. Japanese. Babesia microti cytologically detected in salivary glands of naturally infected tick Ixodesovatus. Journal Article. Microbiol Immunol 49(10), 2005, pp. 12-36.

21. Frolov B.A. Veterinariya. 1985. №11, pp. 48-49.

\section{Список литературы}

1. Захаренко В.А. Биотехнология и защита растений // Защита и карантин растений. 2015. № 11. С. 3-6.

2. International Code of Conduct of the Distribution and Use of Pesticides (Amended version). FAO - Food and agriculture organization of the United Nations, Rome, 1990. 20 p.

3. Шаманская Л.Д. Полифункциональная активность препаратов, полученных на основе природных биологически активных веществ // Сибирский вестник сельскохозяйственной науки. 2012. № 1. С. 53-60.

4. Park K. et al. Variation of antifungal activities of chitosans on plant pathogens // Journal of Microbiology and Biotechnology. 2002. № 12, pp. 84-88.

5. Raafat D., Bargen K., Haas A., Sahl H.G. Insights into the mode of action of chitosan as an antibacterial compound // Applied and Environmental Microbiology. 2008. Jun. № 74 (12), pp. 3764-3773.

6. Пестов А.В. Стоматологические материалы на базехитозана и карбоксиэтилхитозана / Пестов А.В., Бондарь Ю.А., Мирсаев Т.Д., Скорик Ю.А., Ятлук Ю.Г. // Современные перспективы в исследовании хитина и хитозана: материалы Восьмой Международной конференции. Казань, 13-17 июня 2006. Москва, 2006. С. 233-235.

7. Чирков С.Н. Противовирусные свойства хитозана // Новые достижения в исследовании хитина и хитозана: материалы Шестой Международной конференции. М.: ВНИРО, 2001. С. 120-123. 
8. Кожушко И.Б. Действие хитозана на соевую цистообразующую нематоду // Защита и карантин растений. 2003. № 8. С. 29.

9. Penf M.A. Biological pesticidae based on chitosan and entomopathogenic nematodes / Patent EP 1332676 (Bl). FR. Publicationdate 21.07.2004.

10. Гар К.А. Методы испытания токсичности и эффективности пестицидов. M., 1963. $286 \mathrm{c}$.

11. Доспехов Б.А. Методика полевого опыта. М.: Колос, 1986. 502 с.

12. Дезинсекция. Методы определения эффективности инсектицидов, акарицидов, регуляторов развития и репеллентов, используемых в медицинской дезинсекции. NMУ 3.5.2. 1759-03. П. 4.18. Методы оценки эффективности средств (скабицидов) для уничтожения чесоточных клещей. 28 сентября 2003 г. 87 с.

13. Благовещенский Д.И. Методы исследований вшей (Siphunculata). Ленинград: Наука. 1972. 87 с.

14. Верещагин А.Л. Органо-минеральное хитозановое удобрение артемия / Верещагин А.Л., Прищенко Ю.Е., Брюханов В.А., Кузьменко И.А., Антонова О.И. // Производные хитозана и стимуляторы роста в сельском хозяйстве: Материалы 3-ей межрегиональной научно-практической конференции. Бийск: Изд. Алт. гос. тех. ун-та, 2005. С. 5-8.

15. Баташов Е.С. Изучение жирнокислотного состава цист Artemia sp., обитающих в соленых озерах Алтайского края // Производные хитозана в стимуляторы роста в сельском хозяйстве: Материалы 5-й Межрегиональной науч.-практ. конференции 25 марта 2008 года. Бийск. 2008. C. $10-13$.

16. Ильинская Л.И., Озерцовская О.Л. Продукты липоксигепазного окисления жирных кислот как сигнальные молекулы в индуцировании устойчивости растений // Прикладная биохимия и микробиология. 1998. Т. 34, № 5. С. 467-479.

17. Hartung, Thomas, Rauter, Carolin. Prevalence of Borrelia burgdorferi sensu lato genospecies in Ixodesricinus ticks in Europe. A metaanalysis American Society for Microbiology. Applied and Environmental Microbiology. Biological sciences. Vol. 71. No. 11 (November 2005), pp. 7203-7216.

18. Grey J.S., Kahl O.In. Ticks as vectors of zoonotic pathogens in Europe. Halliday R.B., Walter D.E., Proctor H.C., Norton R.A., Colloff M.J., editors. Acarology: Proceedings of the $10^{\text {th }}$ International Congress. Melbourne: CSIRO Publishing; 2001, pp. 547-51.

19. Ruiz-Fons F., Fernández-de-Mera I.G., Acevedo P. et al. Ixodid ticks parasitizing Iberian red deer (Cervus elaphus hispanicus) and European wild boar 
(Susscrofa) from Spain: geographical and temporal distribution // Journal Article, Research Support, Non-U.S. Gov'tVet. Parasitol. Aug 31. 2006. 140 (1-2):133-42.

20. Yano Y., Saito-Ito A., Anchalee D., Takada N. Japanese. Babesia microti cytologically detected in salivary glands of naturally infected tick Ixodesovatus // Journal Article. Microbiol Immunol 49(10), 2005, pp. 12-36.

21. Фролов Б.А. Борьба с эктопаразитами в птицеводческих хозяйствах // Ветеринария. 1985. №11. С. 48-49.

\section{DATA ABOUT THE AUTHORS}

Shamanskaya Lubov Demianovna, Senior Research Officer, Doctor of Agronomical Sciences

Scientifically Research Institute Gardening of Siberia Regional Compartment by name M.A. Lisavenko

49, Zmeinogorskii fas., Barnaul, Russian Federation

niilisavenko@hotbox.ru

Butakov Evgenii Ivanovich, Research Officer

Altai Research Institute of Agriculture

35, Scientific Village, Barnaul, Russian Federation

aniizis@mail.ru

SPIN-code: 9496-7944

\section{ДАННЫЕОБАВТОРАХ}

Шаманская Любовь Демьяновна, старший научный сотрудник, д. с.-х. н. Федеральное государственное бюджетное научное учреждение Научно-исследовательский институт садоводства Сибири М.А. Лисавенко

Змеиногорский тракт, 49, г. Барнаул, Российская Федерация niilisavenko@hotbox.ru

Бутаков Евгений Иванович, научный сотрудник

Федеральное государственное бюджетное научное учреждение Алтайский научно-исследовательский институт сельского хозяйства

Научный городок, 35, г. Барнаул, Российская Федерация aniizis@mail.ru 